\title{
ACCOUNTABILITY, CONTRACT OFFICERS AND THE INTEGRITY OF THE 2012 ELECTION OUTCOME IN GHANA
}

\author{
Ishaq Akmey Alhassan \\ Ishaq Akmey Alhassan is a lecturer at the \\ Madina Institute of Science and Technology, Ghana \\ e-mail: akmey2003@yahoo.co.uk
}

\begin{abstract}
The Electoral Commission of Ghana (EC) has successfully managed five out of the six elections since the adoption of Ghana's 1992 Republican Constitution, which gave legal status to the country's democratisation process despite some administrative lapses over the years. The 2012 presidential election, however, served as a credibility test for the EC. In this paper my main objective is to analyse critically the Ghana 2012 election petition as an expression of mistrust in, and dissatisfaction with, the EC's performance. I argue that, at least in the case of Ghana, the success of an electoral process is largely a function of the human factor, not necessarily the legal frameworks and regulations in force. Using the theory of accountability, I analyse the role of temporary election officers in eroding public confidence in electoral processes. I also draw attention to some implications of Ghana's Supreme Court judgment on election administration in future. My recommendations include punishment for officers whose negligence causes avoidable political tensions, to demonstrate the state's determination to demand accountability from election officers on behalf of citizens. To support this argument, my study uses thematic content analysis of the petitioners' court affidavit, the court's judgment and legal opinions proffered through media outlets.
\end{abstract}

Keywords: election administration, professionalism, public confidence, conflict

\section{INTRODUCTION}

The literature on elections has emphasised the critical role of independent election management bodies in promoting development of democratic governance. 
Since the inception of Ghana's Fourth Republican dispensation, the Electoral Commission of Ghana (EC) has managed all five public elections ${ }^{1}$ that oversaw the alternation of political power between the National Democratic Congress (NDC) and New Patriotic Party (NPP). It has been argued that, but for the successful moderation of electoral contests by the EC, Ghana could have descended into violent electoral conflict similar to that in many other countries (Frempong 2012).

As part of Western-designed post-Cold War reforms in Africa, Ghana transitioned to multiparty democracy in 1993. The processes leading to the final transition, into the Fourth Republican dispensation, were pushed by prodemocracy movements ${ }^{2}$ and supervised by the government of the Provisional National Defence Council (PNDC). They were closely monitored by liberal Western donor countries and institutions.

These processes included four key activities that preceded the landmark 1992 presidential and legislative elections: establishment of the Consultative Assembly to draft a constitution; the 1991 referendum on the draft 1992 Constitution; lifting the ban on political party activity through the passage of the Political Parties Law 1992 (PNDCL 281); and establishment of the Interim National Electoral Commission (Fordwor 2010; Frempong 2012). The Fourth Republic was then inaugurated on 7 January 1993.

Although Ghanaian political parties had attached great importance to elections since 1992, the 2012 presidential election was a crucial one in four main respects. Firstly, it was characterised by the determination of opposition parties to discontinue the 'convention' of successive two-term tenure for an incumbent as enjoyed by the NDC's Jerry John Rawlings (1993-2000) and the NPP's John Agyekum Kufuor (2001-2008) (Table 1). This was judged feasible by especially the largest opposition party, the NPP, which had successfully mounted corruption campaigns against the ruling NDC government ${ }^{3}$. Secondly, the 2012 NPP presidential candidate, Nana Akufo-Addo, did not want to risk going to his party's delegates for a third opportunity to lead the party into another election. Thirdly, the narrow percentage gap (about 3\%) between the two leading contenders in the election gave the NPP even more hope of a possible in-court victory (Table 2). Finally, the post-election petition provided a platform for testing Ghana's electoral laws and constitutional processes.

1 In 1996, 2000, 2004, 2008 and 2012.

2 Including the Movement for Freedom and Justice (MFJ), the National Union of Ghana Students (NUGS), the Ghana Bar Association (GBA) and the Trade Unions Congress (TUC-Ghana).

3 Former president Prof. John E. Atta-Mills won the 2008 election and led the NDC until his death on July 24, 2012. His vice, John Mahama, completed his term and led the party into the 2012 elections. 
Table 1

Performance of NPP and NDC in presidential elections, 1992-2012

\begin{tabular}{|c|c|c|c|c|}
\hline \multirow{2}{*}{ Year } & \multicolumn{4}{|c|}{ Performance (\%) } \\
\cline { 2 - 5 } & NPP & NDC & Others & Total \\
\hline 1992 & 30.29 & 58.40 & 11.31 & 100 \\
\hline 1996 & 39.60 & 57.40 & 3.00 & 100 \\
\hline$* 2000$ & 56.90 & 43.10 & - & 100 \\
\hline 2004 & 52.45 & 44.64 & 2.92 & 100 \\
\hline$* 2008$ & 48.11 & 51.89 & - & 100 \\
\hline 2012 & 47.74 & 50.70 & 1.56 & 100 \\
\hline
\end{tabular}

Source: Author's computation from EC online database http:/ /ec.gov.gh/index.php

* An election year in which a runoff was organised to determine the winner between two main contenders.

Table 2

Final results of the 2012 presidential election

\begin{tabular}{|c|c|c|c|c|}
\hline No & Name of candidate & $\begin{array}{c}\text { Votes } \\
\text { Obtained }\end{array}$ & $\begin{array}{c}\text { Votes } \\
(\%)\end{array}$ & Rank \\
\hline 1 & John Dramani Mahama (NDC) & $5,574,761$ & 50.70 & 1 \\
\hline 2 & Nana Addo Dankwa Akufo-Addo (NPP) & $5,248,898$ & 47.74 & 2 \\
\hline 3 & Papa Kwesi Nduom (PPP) & 64,362 & 0.59 & 3 \\
\hline 4 & Dr Henry Herbert Lartey (GCPP) & 38,223 & 0.35 & 4 \\
\hline 5 & Ayariga Hassan (PNC) & 24,617 & 0.22 & 5 \\
\hline 6 & Michael Abu Sakara Foster (CPP) & 20,323 & 0.18 & 6 \\
\hline 7 & Jacob Osei Yeboah (IND) & 15,201 & 0.14 & 7 \\
\hline \multirow[t]{7}{*}{8} & Akwasi Addai Odike & 8,877 & 0.08 & 8 \\
\hline & Total Valid Votes & $10,995,262$ & & \\
\hline & Total Rejected Votes & 251,720 & & \\
\hline & Total Votes Cast & $11,246,982$ & & \\
\hline & Total Registered Voters & $14,158,890$ & & \\
\hline & Total Constituencies & 275 & & \\
\hline & Turnout $(\%)$ & 79.43 & & \\
\hline
\end{tabular}


This paper presents my critical analysis of the 2012 election petition as an expression of dissatisfaction with the EC's performance. It focuses on the role of temporary electoral officers in eroding public confidence in electoral processes, and draws attention to some implications of Ghana's Supreme Court judgment on electoral administration in future. I argue that at least in the case of Ghana, the success of an electoral process relies largely on the human factor, not necessarily on the legal frameworks and regulations in force. Subsequently, since elections are either won or lost at the polling station, the actions or inaction of such temporary officers pose a danger to the credibility of electoral outcomes and the EC. The paper presents my thematic content analysis of the petitioners' affidavit to the court, the court's judgment and legal opinions proffered through media outlets. In addition, I reviewed literature to provide theoretical and analytical frameworks for the paper.

\section{THEORETICAL FOUNDATION}

In democracies, 'elections are both the supreme political act and a routine administrative exercise' (Pastor 1999, p. 2). Participation in a competitive election is an expression of conflict that requires a reliable management system. Election management is essentially about moderating conflict among political parties competing for power on the basis of ideology and expressed policies and programmes. Election management emerged as a new field of study from the areas of democracy-building and democratic consolidation after the onset of the 'third wave' of democratisation 4 (López-Pintor 2000). This wave ushered in a massive movement of sub-Saharan African countries to democracy in the 1990s (Huntington 1991; López-Pintor 2000).

According to Bratton and Van de Walle (1997, p. 194), 'democratisation involves the construction of participatory and competitive institutions'. This makes electoral management bodies (EMBs) important institutions for countries either transiting into or consolidating their democracies (Pastor 1999; Rosas 2010), because EMBs are the formal entities principally responsible for organising and conducting elections (Mozaffar 2002; Rosas 2010). They 'deal directly with the organisation of multi-party elections and indirectly with governance and the rule of law' (López-Pintor 2000, p. 13). Expectedly, therefore, EMBs are increasingly developing worldwide as permanent and independent commissions mandated to mediate between competing political parties in the quest for political power (López-Pintor 2000). In many countries, however, movement towards

4 For example, the United States' Federal Election Commission was established in 1975; Australia's autonomous Electoral Commission in 1984 (López-Pintor 2000, pp. 15-16). 
independence has been largely cosmetic as executive arms of government and / or their party apparatuses continue to exert influence on EMBs and their operations. Election administration marks the thin divide between success and failure for democracy-building in any country, because the professional character, administrative competence and composition of an EMB have the potential to determine whether an election can be 'a source of peaceful change or cause of serious instability' (Pastor 1999, p. 5; see also Birch 2008; Frempong 2012; Vulchanov 2012). Admittedly EMBs have the responsibility of preserving and strengthening their objective impartiality and credibility in the eyes of the electorate (Birch 2008). For this reason the professionalism of EMBs is essential to building trust and soliciting support from political actors in a democracy. Thus, according to Vulchanov (2012, p. 2):

Professionalism implies transparency, accountability and efficiency of performance of the election administration. These are key factors in ensuring public confidence in the process, including in its outcome. These factors are critical as the election administration makes and implements important decisions that may have an impact on the overall conduct, and even on the outcome, of the elections. Transparent and accountable performance lends integrity to the election process, credibility to election administration bodies and builds public confidence and legitimacy towards the election.

This paper is informed by accountability theory, which is a function of the capacity of the public (the principals) to judge the performance of public officials (their agents) (Gailmardy 2012; Lindberg 2009). To be 'accountable' for an action means to appropriately respond to blame, or praise, related to the action in question (Bennett 2008). Thus accountability is about praiseworthiness, blameworthiness, answerability, liability and attributability (Bennett 2008; Dubnick 2003). It is a legal, political, bureaucratic and moral form of external - that is democratic constraint and control that renders public officials responsible for their decisions and behaviour (Appleby 1952; Dubnick 2003; Gilbert 1959; Marx 1949). In the context of elections, accountability refers to the responsibilities of all state bodies including the election administration, police, prosecutors and judiciary for their actions and inactions that affect the integrity of democratic elections and their outcomes (NDI 2011; Vulchanov 2012).

For the purposes of this paper, accountability is the mechanism through which EMB officials (individually or collectively) are held fully responsible for their actions and inactions that affect the realisation of fair, competitive, democratic elections (Ashworth 2012; Republic of Ghana 1992a; Vulchanov 2012). 
Conceptualised in this sense, offending election officers must be held legally responsible for any acts that violate electoral rules and processes. They must be held thus responsible in order to jealously safeguard the integrity of election outcomes and the confidence placed in actors in EMBs. This kind of accountability is communicated to the citizens through an impartial and fair judicial system. It serves as a check on officials and guarantees the observance of election processes, the integrity of election outcomes and the acceptability of such outcomes to competitors. This form of accountability on the part of election officials should aim ultimately to mitigate past mistakes, enhance future elections and communicate to all citizens that independence of EMBs does not set them above the law. It is acknowledged here that countries may have different procedures for exacting accountability from EMBs through the law courts. However, the baseline should be that political actors and citizens should have confidence in the legal system, such that judgments pronounced would be widely accepted.

Accountability, as described here, does not refer to vertical accountability that deals with voters' verdict on the (potential) performance of political actors through elections. Also, it differs substantially from horizontal accountability that may subject EMBs (as institutions of state) answerable to other institutions in a country. In this sense, individual officials' accountability is a subset of EMB accountability and both can be pursued concurrently. So by deploying the concept of EMB accountability in this paper, we are able to point out some shortcomings of Ghana's Supreme Court judgment on the 2012 petition and explain its associated dangers to the entire electoral system.

It is undeniable that independent permanent EMBs with professional staff tend to operate more efficiently than temporary bodies (Hartlyn, McCoy \& Mustillo 2008; López-Pintor 2000). Indeed, many political actors - albeit sometimes for convenience - do argue that independent EMBs are 'untouchable' in carrying out their mandate. But to what extent should this independence be construed as absolution from accountability? In my opinion, demanding accountability from EMBs, especially in matters of omission and commission of their personnel, should be pursued with urgency and determination. More so, a distinction should not be made between whether the officer involved is a permanent or temporary staff member of an EMB.

In this paper, therefore, I argue that exacting accountability from EMB officials is the surest means of sanitising electoral management processes to arrest potential disputes after election outcomes have been declared. Unless EMB officials recognise that they will be held accountable for actions contrary to laid-down procedures, they will continue to flout such procedures with impunity. And since competitive elections reward or punish policymakers and/ or alternative governments through a formal vertical accountability process, it 
would be suicidal for EMBs to condone acts that give reasons for losing parties to challenge electoral outcomes.

\section{THE EC AND OBLIGATIONS OF PRESIDING OFFICERS}

Ghana's EC is a successor to the four-man Interim National Electoral Commission (INEC) established by the PNDC during the second half of 1991, to oversee all public elections (Frempong 2012). It was established in 1993 in accordance with constitutional provisions (particularly Articles 43 to 54 of the 1992 Republican Constitution) that made the establishment of an electoral management body in Ghana mandatory within six months of the commencement of the Fourth Republic through an Act of Parliament (Frempong 2012; Republic of Ghana 1992b). Thus the Electoral Commission Act (Act 451) of 1993 was passed to give clarity to the constitutional provisions for its composition, function and independence, among others (Frempong 2012; Republic of Ghana 1993). As a seven-member entity, the EC is required by the constitution and Act 451 to be an efficient, non-partisan and independent referee in electoral matters.

According to Frempong (2012, pp. 61-62):

The existence of such body of laws and explicit rules and regulations provided the Electoral Commission with a measure of insulation and put the body in a stronger position lawfully to resist undue external pressures and interference in its work. Above all, the laws formed the framework for the resolution of the electoral conflicts.

The EC has developed various mechanisms for ensuring smooth administration of elections, consensus-building on electoral issues, managing distrust and improving transparency in its activities over the years. Perhaps the most important mechanism in this regard has been the innovative Inter-Party Advisory Committee (IPAC) (Asante 2013; Frempong 2012). As an informal and non-statutory body created in 1994 by the EC, IPAC is a forum where representatives of all political parties and the EC exchange information and discuss programmes and activities of the EC (Asante 2013). Through engagements with IPAC the EC successfully introduced several electoral reforms to Ghana's political landscape. These reforms include the replacement of opaque ballot boxes with transparent ones; the replacement of thumb-printed voter identification cards (IDs) with black-andwhite photo IDs; the introduction of coloured photo IDs; and, in 2012, a biometric voter register and verification system. Through these mechanisms it established that the process of electoral politics depends greatly on its own crucial role visà-vis other stakeholders (Frempong 2008; Frempong 2012). 
Presiding officers constitute the lowest pool in rank, but the largest number of officials, on election day. Each polling station in a public election is manned by a presiding officer with at least one assistant. In 2012 there were 26002 of these officers across the country. Hierarchically, instructions emanate from EC headquarters through district electoral officers and returning officers to presiding officers. Reports on the conduct of an election inversely pass through the same channel back to headquarters (Figure 1).

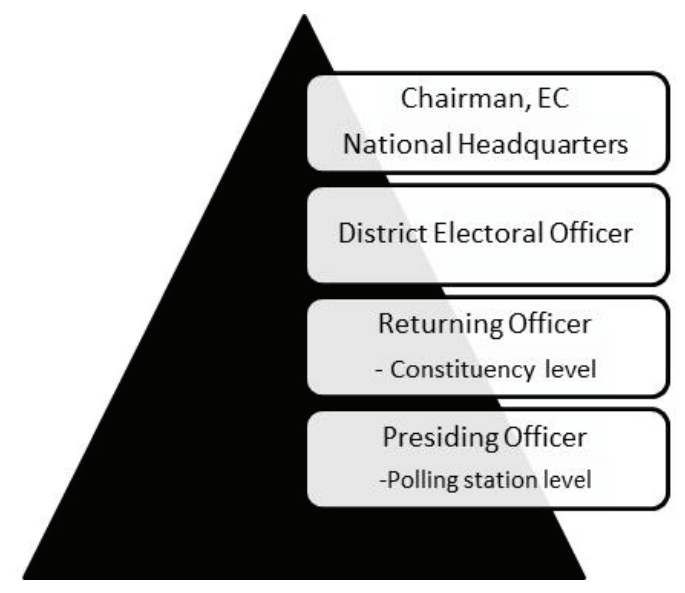

Source: Author's diagram

Figure 1

Hierarchy of election officials

Characteristically, presiding officers are temporary officers who are contracted and trained for a specific election and for a specified period of time. Applicants, who require no specified minimum educational qualifications, sit for a written pre-selection examination organised by the EC. Successful people are then trained and are engaged on election days. This recruitment process has been criticised. For instance, the Institute of Economic Affairs (IEA) has raised doubts over the standard of the examination, the duration of training and the training syllabus's relevance to addressing the complexity of administering contemporary elections (Gyampo 2014). A full assessment of the recruitment and training processes, however, requires a detailed study of such variables as notice of call for applications, the application process, applicants' level of education, applicants' understanding of the electoral process (before and after training) and the syllabus for training, among others. This should be the subject of a separate paper.

In practice the EC has recruited public-sector teachers as presiding officers for all the elections held in Ghana since 1992, except for 2012. For whatever reason, 
the Ghana Education Service decided in 2012 not to release teachers to staff the polling stations. Their absence rendered election results susceptible to more mistakes and inaccuracies compared with previous years. As far back as 1992, the Carter Center observed the need to strengthen the technical knowledge of presiding officers and their polling assistants, to enhance the integrity of election outcomes (Joseph 1992).

Ghana's relevant electoral laws assign the responsibility of managing polling stations to presiding officers. They are directly responsible for their actions or inactions on voting days. As part of their responsibilities, according to Article 17 (2c) of the Public Elections Regulations, 2012 (C.I. 75), a presiding officer is responsible for 'filling in the relevant forms relating to the conduct of the poll' (Republic of Ghana 2012, p. 12). Also, its Article 36 (1 \& 2) clearly states what should be done after ballot papers have been counted in the presence of candidates or their representatives on the closure of polls, and before the results are declared to the public. The presiding officer and the candidates or their representatives shall sign the declaration form that states the number of votes earned by each candidate, the total number of rejected ballots, the name of the polling station and the total number of persons entitled to vote at that polling station (Republic of Ghana 2012). Clearly, C.I. 75 makes it compulsory for all presiding officers to sign election-result declaration forms, before announcing the results to the public and forwarding them to EC headquarters through the returning officer responsible for a constituency and the district electoral officer.

It must be noted that in as much as candidates or their agents may decide not to sign the form, presiding officers do not have that choice. They must sign to certify and declare election results, then communicate any objections raised by candidates or their agents to the returning officer responsible for the constituency under which that polling station falls. The main rationale behind a presiding officer's signature on the form being mandatory is to affirm his or her responsibility to a polling station. In other words, he or she accepts the obligation to answer any questions regarding the execution of all other duties such as setting the polling station, taking proper custody of all election materials and equipment and maintaining order at the station.

That officer remains the only person who can convincingly provide answers to happenings pertaining to their station on election day. In my opinion, therefore, a presiding officer technically negates his or her responsibility by failing to sign a mandatory report (declaration form) on an entire exercise even if he or she carries out all other duties at a station. In this light that officer cannot, and should not be allowed to, escape accountability under the cloak of collective responsibility. 


\section{THE NPP'S ELECTION PETITION}

Ghana has a long history of organising elections, even before independence in 1957, with elections being held in 1951, 1969, 1979, 1992, 1996, 2000, 2004, 2008 and 2012. The country has enjoyed tremendous improvements in the quality of each successive election since the inception of the Fourth Republic (Frempong 2012). Despite these improvements, electoral outcomes have sometimes been received with mixed reactions, depending on political parties' fortunes. Critics of the NPP are quick to accuse it of having a history of rejecting unfavourable election outcomes since 1992. These critics cite the party's vehement rejection of the 1992 presidential election result in declaring it a stolen verdict (New Patriotic Party 1993), and its reluctant acceptance of the 1996 and 2008 results. But the fact remains that despite the NPP's mistrust of some commissioners of the EC, as was the case with the erstwhile INEC (Fordwor 2010; Frempong 2012; Oquaye 1995), it had never directly accused the EC of complicity in election malpractices until December 2012. Indeed, the party has made useful contributions to electoral development in Ghana, in collaboration with other stakeholders. Arguably, therefore, the NPP's challenge to the 2012 election outcome is based on observed trends and patterns of alleged election malpractices about twenty years into the Fourth Republic.

Certain members of the NDC tried to challenge the outcome of the 2004 presidential election in court, but the NPP's challenge to the 2012 outcome is unique and significant in two main respects. Firstly, the leadership of the NPP was unanimous on pursuing court action and managed to gain the support of a larger segment of party members and sympathisers. On the other hand, the NDC leadership was divided on the issue of petitioning the Supreme Court. The party had to abandon filing any petition when it became obvious that its presidential candidate, Prof. John E. Atta-Mills, was not interested in pursuing the case. Secondly, while the NPP was able to convince itself that it had enough evidence to present in court, the NDC failed to convince itself that it had a strong case backed by compelling evidence. This, it is believed, sharply divided the party over whether to initiate court action in the first place. For these and other reasons the NDC abandoned the idea of challenging the 2004 results, which favoured the NPP by $52.45 \%$ to $44.64 \%$ (Electoral Commission of Ghana 2005; Frempong 2012).

Thus for the first time in Ghana's drive towards democratic consolidation and electoral maturity, the NPP became the first to contest the outcome of a presidential election in a court of law. The challenge came nineteen days after the chairman of the EC, Dr. Kwadwo Afari-Gyan, declared John Dramani Mahama the winner of the 2012 presidential election on 9 December 2012, in accordance with Article 63 (9) of the 1992 Constitution of Ghana (Table 2). It is the most recent presidential 
election petition to be determined in Africa beside the 2013 Kenyan petition. Along with these two stand the Nigerian presidential election petitions of 2003 and 2007 and the aborted 2013 Zimbabwean petition, among others. The emerging trend of resorting to courts to resolve electoral disputes is a positive signal that despite their shortcomings, African electoral systems are gradually maturing.

In the case of Kenya, petitions were filed to the court by Raila Odinga and civil society groups challenging the official results that pronounced Uhuru Kenyatta winner of the 4 March 2013 presidential election with $50.07 \%$ of total valid votes cast, as announced by the Independent Electoral and Boundaries Commission (IEBC) on 9 March 2013 (BBC 2013; Herman 2013; Republic of Kenya 2013). Petitioners claimed that systematic 'irregularities had affected the election result and called for fresh elections' (BBC 2013). The principal petitioner, Odinga, alleged on 9 March that the IEBC had fraudulently credited some 1.8 million votes he had earned to Kenyatta. But the IEBC insisted in court that the election 'was credible, despite technical failures with an electronic voter ID system and the vote-counting mechanism' (BBC 2013).

On 28 December 2012, three citizens of Ghana filed a petition in the highest court of the land challenging the result of the 2012 presidential election as announced by the EC. They were Nana Addo Dankwa Akufo-Addo (the NPP's 2012 presidential candidate), Dr. Mahamudu Bawumia (the party's running mate) and Jake Otanka Obetsebi-Lamptey (the party's chairman) as first, second and third petitioners respectively. Joined in the suit were president-elect John Dramani Mahama (the 2012 NDC candidate), the EC and the NDC as the first, second and third respondents respectively. The petitioners jointly sought the declaration that Mahama had not been validly elected as president of the Republic of Ghana; that Akufo-Addo rather was the validly elected president of the Republic of Ghana; and any 'consequential orders as to this Court may seem meet' (Republic of Ghana 2103, p. 3).

The crux of the Ghana 2012 Presidential Election Petition can be summarised in two arguments: (a) that the pre-election processes leading to the election days of 7-8 December were not transparent, particularly with regard to the handling and distribution of the voters' register to competing parties; and (b) that votingday electoral processes were fraught with irregularities and electoral malpractices that affected the determination of a final winner. From the relief sought by the petitioners as stated earlier, it is clear that the central issues at stake before the court were associated with what actually took place on voting days. Indeed, a great deal of the Supreme Court sittings on the case was spent on determination of the second allegation above. This earned the petition the name Pink Sheet petition, in reference to the anomalies (omissions and commissions) observed on declaration forms (the pink-coloured primary records on electoral outcomes) 
from some polling stations. According to the petitioners, the alleged irregularities and electoral malpractices 'were nothing but a deliberate, well-calculated and executed ploy or a contrivance on the part of the 1st and 2nd Respondents with the ultimate object of unlawfully assisting the 1st Respondent to win the 2012 December Presidential Elections' (Republic of Ghana 2013, p. 3).

Six major issues were raised to support their claim of alleged irregularities and malpractices: 'over-voting'; 'voting without biometric verification'; 'absence of the signature of a presiding officer'; 'duplicate serial numbers, i.e. occurrence of the same serial number on pink sheets [declaration forms] for two different polling stations'; 'duplicate polling station codes, i.e. occurrence of different results / pink sheets for polling stations with the same polling station codes'; and 'unknown polling stations, i.e. results recorded for polling stations not on the list of 26002 provided by the 2nd respondent [the EC] for the election' (Republic of Ghana 2013).

Collectively, the petitioners argued that the EC condoned these infractions to benefit the second respondent. Clearly, these are issues that relate to the professional conduct of election officers on polling days. Further, they are acts that cannot be directly blamed on the conduct of political parties or their representatives (officially called polling agents) present at polling stations. To the extent that these irregularities are blameable on officers at polling centres, the argument that the unprofessional conduct of election officers can be dangerous to Ghana's electoral maturity is justifiable.

I share the opinion of Asante (2013) that issues relating to voting without biometric verification, different pink sheets with same serial numbers but different results, and polling stations bearing the same codes but different results could have been addressed had the EC been transparent with political parties at the Inter-Party Advisory Committee (IPAC). Parties could have reached an agreement on what could be done in situations of major failure of verification machines; they would have been made aware that serial numbers are not a security feature of declaration forms but are purely for production purposes; and that some polling stations would have two sets of results bearing the same codes because of 'special voting' organised for security personnel in those stations before the 7-8 December polls.

The petitioners argued that observable inconsistencies between the total number of registered voters as recorded on pink sheets from 11819 polling stations (7 067129 voters) and the number of voters contained on the voters' register for these same polling stations (6 146 572) were indications of over-voting and ballot-stuffing to favour the NDC candidate (Bawumia 2013). To their painstaking analysis, the difference of almost one million votes could not have been accidental. 
Drawing inspiration from Article 49(3) of Ghana's 1992 republican constitution and regulation 36(2) of the Public Elections Regulations, 2012 (C.I. 75), the petitioners questioned the validity of any declared votes that had not been certified by presiding officers of the EC at the polling station. Per Article 49(3) of the constitution,

The presiding officer, the candidates or their representatives and, in the case of a referendum, the parties contesting or their agents and the polling agents if any, shall then sign a declaration stating

a. the polling station, and

b. the number of votes cast in favour of each candidate or question, and the presiding officer shall, there and then, announce the results of the voting at that polling station before communicating them to the returning officer...

(Republic of Ghana 1992b, p. 46)

To the petitioners, therefore, 'the presiding officer has a mandatory constitutional and statutory duty to sign the declaration form at the polling station before he can lawfully declare the results of the polls at that polling station' (Bawumia 2013, p. 10). As a result, they emphasised, the absence of presiding officers' signatures from the declaration forms of 1826 polling stations rendered those votes invalid. Consequently the petitioners requested the court to annul 4547109 of the total valid votes recorded at 11842 polling stations tainted by alleged irregularities. Had the court agreed, about 3084638 votes would have been deducted from those recorded for John Dramani Mahama and about 1462471 from those for Nana Addo Dankwa Akufo-Addo. Thus Akufo-Addo would have emerged as the winner of the 2012 presidential election, with $59.55 \%$ of total valid votes cast (Table 3).

The petitioners also foresaw that the court might not grant all the requested reliefs, and thus suggested possible directions it might consider (Table 4). They further concluded that if only the vote surplus complained of at 2065 polling stations was annulled by the Supreme Court, John Dramani Mahama would get $49.1 \%$ and Nana Addo Dankwa Akufo-Addo 49.3\% of total valid votes cast. Secondly, if only voting without biometric verification at 2279 polling stations was considered, the two rivals would get $49.13 \%$ and $49.38 \%$ respectively of valid votes cast. Thirdly, if votes were annulled on the basis of 'instances of same serial numbers for different polling stations with different results in the 10533 polling stations', they would get $41.1 \%$ and $57.55 \%$ respectively. Finally, if votes at only 1826 polling stations were annulled on the basis of missing signatures of presiding 
Table 3

Total votes earned by contestants after deductions

\begin{tabular}{|l|r|r|r|r|r|}
\hline & \multicolumn{1}{|c|}{$\begin{array}{c}\text { EC } \\
\text { Results }\end{array}$} & $\begin{array}{c}\text { EC } \\
\text { Announced } \\
\%\end{array}$ & \multicolumn{1}{c|}{$\begin{array}{c}\text { Affected } \\
\text { Votes }\end{array}$} & \multicolumn{1}{c|}{$\begin{array}{c}\text { Valid } \\
\text { Votes }\end{array}$} & $\begin{array}{c}\% \text { of Total } \\
\text { Valid } \\
\text { Votes }\end{array}$ \\
\hline John Mahama & $5,574,761$ & 50.70 & $3,084,638$ & $2,490,123$ & 39.17 \\
\hline Henry Lartey & 38,223 & 0.30 & 19,629 & 18,594 & 0.29 \\
\hline Nana Akufo-Addo & $5,248,898$ & 47.70 & $1,462,471$ & $3,786,427$ & 59.55 \\
\hline Paa Kwesi Nduom & 64,362 & 0.60 & 32,239 & 32,123 & 0.51 \\
\hline Akwasi Addai Odike & 8,877 & 0.10 & 4,713 & 4,164 & 0.07 \\
\hline Hassan Ayariga & 24,617 & 0.20 & 14,129 & 10,488 & 0.16 \\
\hline Abu Sakara & 20,323 & 0.20 & 10,497 & 9,826 & 0.15 \\
\hline Jacob Osei Yeboah & 15,201 & 0.10 & 8,989 & 6,212 & 0.10 \\
\hline TOTAL & $10,995,262$ & 100.00 & $4,637,305$ & $6,357,957$ & 100.00 \\
\hline
\end{tabular}

Source: Bawumia 2013 (p. 18)

Table 4

Candidates' performance after NNP's suggested annulments (\%)

\begin{tabular}{|l|c|c|c|c|}
\hline & \multicolumn{3}{|c|}{ Basis for Annulment of Votes } \\
\cline { 2 - 5 } & Over-voting & $\begin{array}{c}\text { Voting } \\
\text { without } \\
\text { verification }\end{array}$ & $\begin{array}{c}\text { Same serial } \\
\text { numbers }\end{array}$ & $\begin{array}{c}\text { Absence } \\
\text { of } \\
\text { signatures }\end{array}$ \\
\hline John D. Mahama & 49.1 & 49.13 & 41.10 & 49.45 \\
\hline Nana A.D. Akufo-Addo & 49.3 & 49.38 & 57.55 & 49.03 \\
\hline All other contestants & 1.6 & 1.49 & 1.35 & 1.52 \\
\hline Total & 100 & 100 & 100 & 100 \\
\hline
\end{tabular}

Source: Author's compilation from Bawumia's affidavit (pp.18-19) 
officers, Mahama would get $49.45 \%$ and Akufo-Addo $49.03 \%$. It is worth noting that in all but the third scenario a run-off would have been necessary, because a winner needs to win $50 \%$ plus one vote.

In the conclusion to their court affidavit, as prepared and presented by the second petitioner on behalf of the first and third, they observed:

That as a matter of fact, however, these violations, irregularities and malpractices occurred in different combinations in as many as 11842 polling stations. In the result, I am advised by counsel and verily believe same to be true that what must be taken into account is the impact of the combined effect of these violations, irregularities and malpractices on the outcome of the election as declared by the 2 nd Respondent. ...

That I say if the impact of the combined effect of these violations, irregularities and malpractices on the outcome of the election as declared by the 2nd Respondent is taken into account, the 1st Petitioner is the person who ought to be declared as having been validly elected as President of the Republic of Ghana.

(Bawumia 2013, pp. 18-19)

In effect the petition sought to question the integrity of the EC and further buttress the mistrust that has often lingered in losing political parties after almost all elections organised in the Republic of Ghana so far. As argued by Frempong (2012), the NPP in particular has harboured 'suspicion and mistrust of the election authority as an independent and impartial arbiter' (p. 62) partly because its present composition is the creation of the PNDC/NDC government.

The NPP's petition and the relief sought from the court share some similarities with those of Kenya. Originally filed as three separate petitions on 14 and 16 March 2013, the Kenyan Supreme Court ordered on 25 March the same year that they be consolidated. After the consolidation the court agreed with all parties involved on four issues to be tried. These were the validity of declaring Kenyatta the winner of the election; the credibility of the electoral process; the effects of rejected ballots on the final votes tallied for each candidate; and other orders and reliefs the court might deem fit (Republic of Kenya 2013). The petitioners' concern regarding the first three issues related to electoral irregularities at poll centres. They believed, like their counterparts in Ghana, that the irregularities were wilfully planned and executed by election officials to favour Kenyatta and his deputy. 


\section{THE SUPREME COURT JUDGMENT}

Without delving into the details of the court's judgment on the petition, it suffices to note the cumulative effect of the combined views of the nine judges hearing the matter. On 29 August 2013 the judges, presided over by Justice William Atuguba, ruled against the petitioners by a majority of five to four. Despite the NPP's denial that it received a fair verdict from the court, and a plethora of analyses that followed, the landmark ruling succeeded in arresting the apprehension and uncertainty characterising the entire trial period. The ruling notwithstanding, several recommendations were proffered to the EC (the second respondent) as directions for necessary reforms to Ghana's electoral system. The recommendations included raising the calibre of presiding officers, simplifying the pink sheet and streamlining the biometric device system to avoid breakdowns.

The judgment observed that the petitioners had failed to prove the allegation that the second respondent superintended over 'deliberate, well-calculated and executed' irregularities and electoral malpractices to help the first respondent win the December 2012 presidential election (Republic of Ghana 2013). For instance, the court observed that:

We were at a loss as to how the embossment of the same number on more than one pink sheet whether serial or otherwise in respect of two different polling stations has impacted adversely on the 2012 electoral process. Those numbers, on the evidence of Dr. Afari Gyan the Electoral Commission's chairman, are the offshore generation of the printers of the pink sheets. Those numbers have no statutory base. However the decisive fact is that their incidence has not been shown to have any detrimental effect on the electoral process. We felt that grounds V [i.e. duplicate polling station codes] and VI [i.e. unknown polling stations] did not relate to matters that could have any substantial effect on the declared results. We therefore dealt mainly with the first three grounds of the petition. Nonetheless, for the easy future ascertainment of the number and electoral location of pink sheets in the electoral process their numbering should be streamlined.

(Republic of Ghana 2013, p. 4)

The first three grounds of the petition dealt with - and subsequently dismissed - were over-voting, voting without biometric verification, and absence of the signature of a presiding officer on a pink sheet. Of these irregularities, that which most engaged and sharply divided the court as to its consequence was 'absence 
of the signature of a presiding officer' (Republic of Ghana 2013, p. 4). Should it or should it not declare the absence of a presiding officer's signature consequential to the outcome of the presidential election? The court did not cancel votes on affected declaration forms from the nationwide 26002 polling stations; rather it protected the rights of voters by validating the votes recorded.

The judgment indicates that the people's franchise must be jealously guarded and that individual officers' omissions must not be visited on innocent electorates. By its choice the court sealed a dangerous avenue through which corrupt presiding officers could sabotage opponents of their preferred political parties in unfriendly electoral areas. It must be noted, as has been argued by some political observers, that by rejecting the petitioners' request, the court set a precedent that acts of commission and omission on election declaration forms will in future not necessarily hold any consequences for the final determination of election outcomes. This argument is, however, a very weak one.

Citing its duty to preserve the letter and spirit of the constitution, the Supreme Court affirmed that it reserved the right to rectify any error committed in any statute or the constitution itself (Republic of Ghana 2013). Thus it ruled:

It is undoubtable that in some instances the declared results were not signed by the presiding officer though the petitioners' polling agents did sign. The crucial question that has devastated this court is whether those results should be annulled. To arrive at an answer to this question a number of considerations are relevant. To some minds the sacred nature of the constitution and the clarity of article 49 so far as the requirement of the presiding officer's signature is concerned warrant the unmitigated annulment of the votes involved. Quite clearly however this has not been the approach of this court and its predecessors to constitutional construction or application.

(Republic of Ghana 2013, p. 5)

In modern times the courts do not apply or enforce the words of statutes but their objects, purposes and spirit or core values. Our constitution incorporates its spirit as shown for example, in article $17(4)(d)$. This means that it should not be applied to satisfy its letter where its spirit dissents from such an application

(Republic of Ghana 2013, pp. 45-46)

Thus, as in Kenya, the relief sought by the petitioners was not granted. In both cases the EMB's declarations were validated and EMB officers left unpunished. While Ghana's Supreme Court arrived at a majority decision, in Kenya six judges 
chaired by Chief Justice Willy Mutunga on 30 March 2013 unanimously declared the Kenyan poll free and fair. This difference notwithstanding, both rulings leave in their wake questions about their implications for future elections. Precedent has thus been set on aspects of election management in Ghana.

\section{IMPLICATIONS OF THE SUPREME COURT JUDGMENT}

Although the Supreme Court's judgment succeeded in settling the immediate conflict brought before it, the judgment set a legal precedent that could have grave consequences for Ghana's electoral management system. Why were offending presiding officers not allowed to address in court issues pertaining to their professional conduct? Suggestions that such an exercise may have prolonged the period for determining the issues raised in the petition clearly denied citizens the opportunity to know exactly what had gone wrong. Neither could their absence from court explain the slim majority decision against the petition.

Offending presiding officers from the stations affected should have been punished by the court even after it had protected voters' rights. This opinion is based on the fact that their actions and/or inactions affected the integrity of the election and its outcome. In fact the EC's own court evidence, of 905 erring presiding officers against the petitioners' alleged 2009, is still too many. By failing to punish them for their failure to adhere strictly to procedure, the Supreme Court concluded that election officials may at any point act contrary to electoral rules, yet go unpunished. The danger in this is that people entrusted with the responsibility of safeguarding the nation's electoral processes could feel 'untouchable' even when they act irresponsibly. In my view, the failure of presiding officers to sign primary election records constitutes a criminal offence under C.I. 75 and PNDCL 284.

Punishing erring election officers is necessary for several reasons. Firstly, sanctioning officers for any action or inaction is inherent to the principle of accountability (Lindberg 2003). Secondly, their failure to act as required by law denied citizens freedom from fear, an aspect of human security. In fact the entire duration of the court's hearing was accompanied by national prayers, peace campaigns and anxiety - just as in the pre-election period. One may argue that this kind of ambience was an extension of the extremely tense atmosphere that characterised the 2008 elections. However, the spontaneous vandalism in parts of Accra preceding the 2012 petition, and the accompanying fear, were unprecedented. Incidents of that nature are 'typical of what occurs when a "technical irregularity" intersects with political suspicions' (Pastor 1990, p. 2). Had the NPP not abandoned its initial intention to stage Ghana's version of the Arab Spring at the Obra Spot in Accra, human insecurity would have degenerated from 
the presence of excessive fear to people's inability to meet their wants. Luckily Ghana narrowly escaped post-election violent conflict for the second time.

The third reason why erring officers should have been punished is the need to stop, or at least minimise, the emerging trend of sponsoring card-bearing political party members for positions in EC offices. Generally parties consider the existence of loyalists at polling stations an important internal strategy for winning a contest. Arguably, petitioners are aware of the effectiveness of this illegal strategy and its potential deployment by political parties. Parties could also not underrate the allegation that some presiding officers applied dark cream to their hair, rubbed their fingers through it during ballot counting, and then used their stained fingers to impress multiple thumb prints on ballot papers during 2008 general elections. The problem of rejected ballots after every election could probably be solved if attention was given to this alleged practice. Although not based on any scientific estimation, it is an open secret that no fewer than $75 \%$ of presiding officers are either members or sympathisers of the NDC or NPP.

But why did the court choose not to punish offending presiding officers? Was their failure to properly fill in pink sheets (leading to the petitioners' allegation of over-voting), or to sign them, not offensive conduct? Article 17(5) of C.I. 75 describes contravention of the laws and regulations governing the conduct of elections by a presiding officer or polling assistant as offences 'liable to sanctions applicable under the electoral laws of Ghana' (Republic of Ghana 2012, p. 12). Indeed, the petitioners did not specifically ask the court to punish them. In my opinion, this decision was made to ensure consistency with the decision on the non-consequentiality of the absence of signatures. Had the court punished the offending officers, questions would have been raised about the validity of votes recorded on the affected pink sheets. Simply put, the arguments raised by the petitioners would have been validated by the court, leading to an appeal for a review of the ruling and possible cancellation of the affected votes. Whether such cancellation would have favoured the NPP's candidate, as claimed by the petitioners, would have been another issue.

Another reason could be because C.I. 75 falls short of prescribing punishments for defaulting presiding officers. If so, did it escape all the nine judges that a complementary law exists in the statutes? As argued by lawyer Ayikoi Otoo, other legal provisions could have been referred to in exacting full accountability from presiding officers (see myjoyonline.com 2014b). Otoo cited, for example, section 30 (Offences of Electoral Officers) of the Representation of the People Law, 1992 (PNDCL 284), which provides answers to how the state should deal with erring election officials. In terms of this section, among other offences, an -

election officer, clerk, interpreter or other person who has a duty to perform, whether under this Law or otherwise, in relation to an 
election and who ... without reasonable cause acts or fails to act in breach of his official duty commits an offence and is liable on

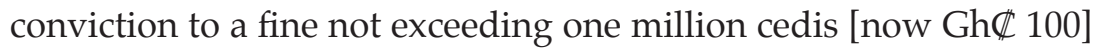
or to imprisonment or to a term not exceeding two years or both

(Republic of Ghana 1992a, p. 21)

Based on the above provision, perhaps the court would have considered sentencing each erring officer to two years in prison instead of imposing a fine of GHÆ100 (equivalent to $\$ .025 .72$ as at 20 June 2016). This is because, unless revised to reflect current economic situations, imposing a fine would be less of a deterrent. Whatever the case might be, the whole nation lost the opportunity to see them answer for any alleged infraction. Although we might not agree with aspects of the court's ruling, as confidently expressed by Odinga in a news conference after the Kenyan verdict (BBC 2013), our belief in constitutionalism should remain supreme. Perhaps Justice Robert H. Jackson's comment on US Supreme Court decisions is reassuring: 'We are not final because we are infallible, but we are infallible only because we are final' (quoted in Maina 2013).

\section{CONCLUSION}

Arguably, the EC has improved its performance with each succeeding election by learning from past mistakes and scaling up good practices (Frempong 2012). The petitioners' emphasis on over-voting and missing presiding officers' signatures, however, raises questions about the capacity of these officers to manage polling station processes efficiently. Arguments have been raised by the EC and others that pressure at stations could lead to mistakes on the part of officers. Indeed, human error happens sometimes and mistakes might not affect electoral credibility if they are random and do not cumulatively determine the outcome of an election (Elklit \& Reynolds 2005; Mozaffar \& Schedler 2002). In the present case, though, to describe irregularities at no fewer than 905 stations as mere human error is difficult to understand. It is not a good enough excuse, because elections are won and lost at the polling station in Ghana's electoral system. So it is in the interest of political parties to jealously raise issues considered to be contrary to electoral rules. Moreover, just as a slight thumb-printing mistake on the part of voters renders their votes invalid, an election officer's mistake should carry equal weight.

Perhaps, had Alex Frempong considered the 2012 elections in his analysis of electoral politics in Ghana's Fourth Republic, he would not have concluded that 'professional election administration has been the linchpin of Ghana's electoral success' (Frempong 2012, p. 145). 
Items of evidence presented before the Supreme Court necessitate a second look at the professionalism exhibited by contracted EC officials at polling station level. Indeed, an officer's level of formal education might be just one of the indicators of professional conduct. In the preparation of election declaration forms, however, proficiency particularly in written language is extremely important. This is why the IEA should be commended for recommending that reasonable educational qualifications be demanded from recruited presiding officers. It is also why the EC should consider revising the syllabus for training selected applicants (Gyampo 2014). Certainly, technical incapacity of election officers leads to political suspicion that convinces one party its opponents benefited from an observed technical irregularity (Pastor 1999). Such suspicions have caused the failure of many elections in Africa and elsewhere. My analysis in this paper is fully aligned with IEA's position that:

Where they [presiding officers] perform their duties efficiently, the credibility of the poll is guaranteed; but where they are incompetent and act negligently, they compromise the polls and undermine the nation's electoral process. In the nation's drive towards democratic maturity and quest for credible, transparent and acceptable elections, there is the need for a rethink of the calibre of people recruited as election officials.

(Gyampo 2014)

When one looks critically at the petition from this perspective, it is fair to conclude that it was presiding officers who succeeded in holding the nation to ransom for the eight months of the court hearing. The hearing diverted attention from debates on national development issues to polarised political debates; it distracted the government, although a caretaker one, from attending to serious business of governance; and it potentially diverted foreign direct investment away from the country. This defeats the position taken by a section of Ghanaians who blame the petitioners for having created a condition of anxiety, insecurity and tension in the country. Erring presiding officers were fully to blame.

Indeed, elections are won and lost at the polling station. As such, a clear signal should be sent to election officers of all categories that the nation is ready to hold every officer legally responsible for actions or inactions in electoral matters. It is in Ghana's national interest to ensure that measures are taken to safeguard the integrity of electoral processes and their outcomes. The words of the first petitioner, Nana Akufo-Addo, after the Supreme Court verdict, are important in this regard. To him, and to all politicians: 
It is painful enough to lose an election, I can testify to that; but the pain should not come with a suspicion of having been cheated. We should be able to congratulate the winner enthusiastically and extend the support needed for our many problems to be tackled.

(citifmonline.com 2014)

\section{ACKNOWLEDGEMENT}

I would like to thank Mahmud Mukhtar Muhammed, a master's student at the University for Development Studies, Ghana, for his critical input to this paper.

- REFERENCES -

Appleby, PH 1952, Morality and administration in democratic government, Louisiana University Press, Baton Rouge, LA.

Asante, R 2013, 'Making democracy work? Quasi-public entities and the drama of elections in Ghana', Journal of African Elections, vol. 12, no. 2, pp. 56-74.

Ashworth, S 2012, 'Electoral accountability: recent theoretical and empirical work', Annu. Rev. Polit. Sci., vol. 15, pp. 183-201.

Bawumia, M 2013, Affidavit of Dr. Mahamudu Bawumia pursuant to the court directions on memorandum of issues and mode of trial dated 2nd April 2013, Supreme Court of Ghana, Accra.

BBC 2013, 'Kenya Supreme Court upholds Uhuru Kenyatta election win'. Available at http:/ / www.bbc.com/ news / world-africa-21979298 [Accessed 11 January 2014]

Bennett, J 2008, 'Accountability (II)', in M McKenna \& P Russell (eds), Free will and reactive attitudes: perspectives on P.F. Strawson's 'Freedom and Resentment', Aldershot, Ashgate.

Birch, S 2008, 'Electoral institutions and popular confidence in electoral processes: a cross-national analysis', Electoral Studies, vol. 27, no. 2, pp. 305-320.

Bratton, M \& de Walle, NV 1997, Democratic experiments in Africa: regime transitions in comparative perspective, Cambridge University, Cambridge.

Citifmonline.com 2014, 'Election petition verdict was painful - Akufo-Addo'. Available at http:/ / www.citifmonline.com/2014/08/29/election-petitionverdict-was-painful-akufo-addo/ [Accessed 7 September 2014].

Dubnick, MJ 2003, 'Accountability and ethics: reconsidering the relationships', International Journal of Organization Theory and Behavior, vol. 6, no. 3, pp. 405-441.

Electoral Commission of Ghana 2005, Election 2004: Ghana's parliamentary and presidential elections, Electoral Commission of Ghana, Accra. 
Electoral Commission of Ghana 2012, Election Results Sunday, 9 December 2012. Available at http://media.myjoyonline.com/ docs / 201212/2012finalresults.pdf [Accessed 17 December 2013].

Elklit, J \& Reynolds, A 2005, 'A framework for the systematic study of election quality', Democratization, vol. 12, no. 2, pp. 147-162.

Fordwor, KKD 2010, The Danquah-Busia tradition in the politics of Ghana: the origins, mission and achievements of the New Patriotic Party, Unimax MacMillan Ltd, Accra.

Frempong, AKD 2008, 'Innovations in electoral politics in Ghana's fourth republic: an analysis', in C Raventos (ed), Democratic innovation in the south: participation and representation in Asia, Africa and Latin America, CLACSO Books, Buenos Aires.

Frempong, AKD 2012, Electoral politics in Ghana's Fourth Republic: in the context of post-Cold War Africa, Yamens Press Ltd, Accra.

Gailmard, S 2014, 'Accountability and principal-agent theory', in M Bovens, RE Goodin \& T Schillemans (eds), The Oxford handbook of public accountability, Oxford University Press, Oxford.

Gilbert, CE 1959, 'The framework of administrative responsibility', Journal of Politics, vol. 21, no. 3, pp. 373-407.

Gyampo, R 2014, 'The IEA electoral reform project recommendation 3 (three): recruit highly trained election officials and punish them when they act negligently'. Viewed 29 December 2014, http:/ / ieagh.org/the-iea-electoral-reformproject-recommendation-3-three-recruit-highly-trained-election-officialsand-punish-them-when-they-act- negligently/\#sthash.fkbZJxM8.dpuf

Hartlyn, J, McCoy, J \& Mustillo, TM 2008, 'Electoral governance: matters explaining the quality of elections in contemporary Latin America', Comparative Political Studies, vol. 41, no. 1, pp. 73-98.

Herman, C 2013, 'The adjudication of Kenya's 2013 election: public perception, judicial politics, and institutional legitimacy'. Viewed 15 May 2014,

http: / / digitalcollections.sit.edu / cgi/ viewcontent.cgi?article=2518\&context=isp_collection

Huntington, SP 1991, The third wave: democratization in the late twentieth century, University of Oklahoma Press, Norman OK.

Joseph, R 1992, Report of the Carter Center on the Ghana election mission, November 6, 1992. Available at: http:/ / cartercenter.org/documents/electionreports / democracy / Final ReportGhana1992.pdf

Lindberg, SI 2003, 'It's our time to "chop": do elections in Africa feed neopatrimonialism rather than counter-act it?', Democratization, vol. 10, issue. 2. Lindberg, SI 2009, 'Accountability: the core concept and its subtypes', Working Paper No. 1, Overseas Development Institute (for Africa Power and Politics Programme), London. 
López-Pintor, R 2000, Electoral management bodies as institutions of governance, UNDP Bureau for Development Policy, New York.

Maina, W 2013, 'Verdict on Kenya's presidential election petition: five reasons the judgment fails the legal test'.

http://www.theeastafrican.co.ke/OpEd/comment/Five-reasons-Kenya-Supreme-Court-failed-poll-petition-test/-/434750/1753646/-/297c6q/-/index.html

Marx, FM 1949, 'Administrative ethics and the rule of law', American Political Science Review, vol. 43, no. 6, pp. 1119-1144.

Mozaffar, S \& Schedler, A 2002, 'The comparative study of electoral governance introduction', International Political Science Review, vol. 23, no. 1, pp. 5-27. Mozaffar, S2002, 'Patterns of electoral governance in Africa's emerging democracies', International Political Science Review, vol. 23, no. 1, pp. 85-101.

Myjoyonline.com 2014a, 'IEA recommends prison sentences for negligent EC officers'. Available at http://myjoyonline.com/politics/2014/September5th/iea-recommends-stiffer-punishment-prison-sentences-for-negligent-ecofficers.php

Myjoyonline.com 2014b, 'Erring presiding officers can be jailed for 2 years Ayikoi Otoo'. Available at http:/ / www.ghanaweb.com/GhanaHomePage/ NewsArchive/ artikel.php?ID=325015

National Democratic Institute for International Affairs (NDI) et al. 2009, Colloquium on African elections: best practices and cross-sectoral collaboration, Final Report, Accra, Ghana 11-14 November 2009, Viewed 20 December 2013, https: / / www.ndi.org / files / African_Elections_Best_Practices_ENG.pdf

National Democratic Institute for International Affairs (NDI) 2011. Electoral transparency, participation and accountability: a guide to best practice in transparency, accountability and civic engagement across the public sector, Transparency \& Accountability Initiative, London.

New Patriotic Party 1993, The stolen verdict: Ghana November 1992 presidential election, report of the New Patriotic Party, New Patriotic Party, Accra.

Oquaye, M 1995, 'The Ghanaian elections of 1992 - a dissenting view', African Affairs, vol. 94, no. 375, pp. 259-275.

Pastor, RA 1999, 'The role of electoral administration in democratic transitions: implications for policy and research', Democratisation, vol. 6, no. 4, pp. 1-27. Republic of Ghana 1992a, Representation of the People Law, 1992 (PNDCL 284), Assembly Press, Accra.

Republic of Ghana 1992b, The 1992 Constitution of The Republic of Ghana, Ghana Publishing Company Limited, Tema.

Republic of Ghana 1993, The Electoral Commission Act (Act 451) of 1993, Assembly Press, Accra. 
Republic of Ghana 2012, Public Elections Regulations, 2012 (C.I. 75), Assembly Press, Accra.

Republic of Ghana 2013, 'Supreme Court election petition judgment'. Viewed 18 September 2013,

http://www.africanelections.org/ghana/ news_detail.php?nws=7239\&t=Final\%20Verdict:\%206hana\%20Elections\%202012\%20Petition

Republic of Kenya 2013, 'Full judgment - petition No. 5 of 2013', Available at: http:/ / www.icj-kenya.org/dmdocuments/papers/ full\%20judgement-petition $\% 20$ no.\%205\%20of\%202013.pdf

Rosas, G 2010, 'Trust in elections and the institutional design of electoral authorities: evidence from Latin America', Electoral Studies, vol. 29, no. 1, pp. 74-90.

Vulchanov, N 2012, 'The organisation of elections by an impartial body', a paper presented at the Conference on 'The European electoral heritage: ten years of the code of good practice in electoral matters', organised by the European Commission For Democracy Through Law (Venice Commission), Tirana, Albania, 2-3 July 2012. 